\title{
Pengaruh Nilai Tukar, Pertumbuhan Ekonomi, Inflasi, dan Suku Bunga terhadap Investasi Asing Langsung di Indonesia
}

\section{The Effect of Exchange Rate, Economic Growth, Inflation, and Interest Rate on Foreign Direct Investment in Indonesia}

\author{
Nadya Khodijah Putri ${ }^{*}$, Komara ${ }^{1}$ \& Tupi Setyowati ${ }^{1}$ \\ 1) Program Studi Manajemen, Fakultas Ekonomi dan Bisnis, Universitas Muhamadiyah Prof. DR. \\ HAMKA \\ *Coresponding Email: nadyakhodijahputri@gmail.com
}

\begin{abstract}
Abstrak
Penelitian ini bertujuan untuk mengetahui pengaruh antara nilai tukar rupiah, pertumbuhan ekonomi, tingkat inflasi dan tingkat suku bunga terhadap investasi asing langsung. Dalam penelitian ini digunakan metode kuantitatif. Sampel dalam penelitian ini antara lain, nilai foreign direct investment net inflow, official exchange rate, gross domestic product per capita, consumer price index dan lending, interest rate di Indonesia periode tahun 1994-2019. Data yang digunakan dalam penelitian ini merupakan data sekunder yang diperoleh dari website World Bank. Teknik pengolahan dan analisis data yang di gunakan adalah analisis statistik deskriptif, regresi linear berganda, uji asumsi klasik, analisis koefisien korelasi, dan uji hipotesis. Hasil penelitian menunjukkan bahwa secara parsial nilai tukar Rupiah memiliki pengaruh negatif dan signifikan terhadap investasi asing langsung, pertumbuhan ekonomi memiliki pengaruh positif dan signifikan terhadap investasi asing langsung, inflasi memiliki pengaruh positif dan signifikan terhadap investasi asing langsung dan suku bunga memiliki pengaruh negatif dan signifikan terhadap investasi asing langsung terhadap investasi asing langsung. Secara simultan nilai tukar rupiah, pertumbuhan ekonomi, inflasi dan suku bunga memiliki pengaruh yang signifikan terhadap investasi asing langsung di Indonesia.
\end{abstract}

Kata Kunci: Nilai Tukar Rupiah, Pertumbuhan Ekonomi, Tingkat Inflasi, Tingkat Suku Bunga, Investasi Asing Langsung.

\begin{abstract}
This study aims to determine the effect of the rupiah exchange rate, economic growth, inflation rates and interest rates on foreign direct investment. this study use quantitative methods. The samples in this study are the value of the foreign direct investment net inflow, the official exchange rate, the gross domestic product per capita, the consumer price index and the lending interest rate in Indonesia in the period 1994-2019. The data used in this study are secondary data obtained from the World Bank website. Data processing and analysis techniques used are the descriptive statistics analysis, the multiple linear regression, the classic assumption tests, the correlation coefficient analysis, and the hypothesis testing. The results showed that the rupiah exchange rate partially had a negative and significant effect on the foreign direct investment, the economic growth had a positive and significant effect on the foreign direct investment, the inflation rate had a positive and significant effect on the foreign direct investment and the interest rate had a negative influence and significant impact on the foreign direct investment against foreign direct investment. Simultaneously, the Rupiah exchange rate, economic growth, inflation, and interest rates have a significant influence on the foreign direct investment in Indonesia.
\end{abstract}

Keywords: Rupiah Exchange Rate, Economic Growth, Inflation, Interest Rate, Foreign Direct Investment.

How to Cite: Putri, N.K., Komara, \& Setyowati, T. (2021). Pengaruh Nilai Tukar, Pertumbuhan Ekonomi, Inflasi, dan Suku Bunga Terhadap Investasi Asing Langsung di Indonesia. JKBM (Jurnal Konsep Bisnis dan Manajemen). 8 (1): 11-25 
Putri, N.K., Komara, \& Setyowati, T. (2021). Pengaruh Nilai Tukar, Pertumbuhan Ekonomi, Inflasi, dan Suku Bunga ...

\section{PENDAHULUAN}

Globalisasi saat ini membawa Indonesia berada di tengah-tengah interaksi dengan berbagai negara di dunia. Salah satu bentuk dari meningkatnya integrasi perekonomian dari globalisasi yaitu hilangnya batasan-batasan dalam bisnis internasional, sehingga memudahkan terjadinya kerjasama ekonomi internasional antar berbagai negara di dunia. Hilangnya batasan-batasan tersebut membuat kerjasama ekonomi Internasional negara Indonesia dengan negara lain menjadi jauh lebih mudah. Salah satu manfaat dari kerjasama ekonomi internasional ini dapat mempermudah masuknya invetasi dari negara lain ke dalam negeri.

Investasi merupakan salah satu faktor penting dalam peningkatan perekonomian suatu negara. Salah satu bentuk investasi yang berasal dari negara lain yaitu investasi asing langsung atau biasa disebut dengan Foreign Direct Investment (FDI). Menurut UNCTAD dalam Mayes et al. (2015) Foreign Direct Investment/ FDI merupakan investasi yang dilakukan oleh perusahan kepada perusahan di negara lain dengan tujuan mengendalikan operasi di negara tersebut. Foreign Direct Investment/FDI merupakan investasi yang berasal dari luar negeri dengan cara menginvestasikan dananya pada aset-aset yang produktif, sperti pabrik, lahan ataupun peralatan lain penunjang perusahaan.

Alasan yang menjadikan investor dari negara maju menginvestasikan dananya di negara yang berkembang diantaranya adalah, upah tena- ga kerja di negara berkembang yang jauh lebih rendah dibandingkan dengan upah di negara maju hal ini merupakan salah satu upaya untuk mengurangi biaya produksi, memperluas usaha dan pemasaran sehingga meningkatkan profitabilitas, banyak negara berkembang yang merupakan penghasil bahan baku sehingga mempermudah negara maju untuk mendapatkan bahan baku dan sebagainya. Sedangkan untuk negara tempat berinvestasi atau negara berkembang, kehadiran investor asing dalam bentuk FDI. FDI memberikan beberapa keuntungan untuk negara yang dijadikan tujuan investasi antara lain, bertambahnya lapangan pekerjaan untuk masyarakat di negara berkembang yang akan meningkatkan pendapatan masyarakat, peningkatan pendapatan negara melalui pajak, transfer teknologi dari negara maju ke negara berkembang, serta peningkatan kualitas tenaga kerja dalam negeri melalui pelatihan tenaga kerja.

Di Indonesia kinerja FDI masih sangat membutuhkan perhatian yang lebih untuk meningkatkan perekonomian negara. Selama ini, investasi asing yang masuk ke Indonesia lebih banyak berbentuk investasi portofolio yang berbentuk saham ataupun obligasi (mudah keluar dan masuk/jangka pendek). Indonesia perlu mendorong FDI untuk menguatkan perekonomian. Upaya untuk meningkatkan FDI di Indonesia dalam lima tahun terakhir berjalan lambat dan kurang optimal. Sejalan dengan permasalahan tersebut, berikut adalah data terkait FDI di Indonesia selama sepuluh tahun terkahir. 


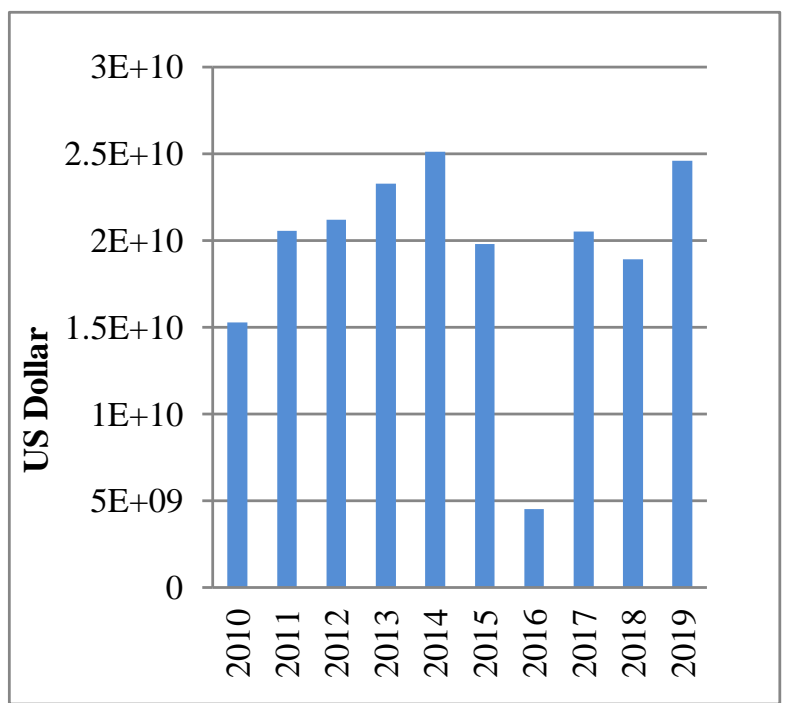

Gambar 1. Grafik Pertumbuhan Foreign Direct Investment Net Inflows Indonesia periode 2010-2019 Sumber : World Bank (https://www.worldbank.org)

Dapat dilihat berdasarkan grafik di atas, kestabilan ekonomi yang merupakan salah satu FDI Net Inflows Indonesia sepuluh tahun terakhir, menunjukan bahwa arus masuk FDI di Indonesia masih belum Optimal. Terlihat jelas pada tahun 2015 dan 2016 FDI Net Inflows Indonesia mengalami penurunan yang sangat signifikan. Menurut Samora (2018) penyebab lesunya investasi selama sepuluh tahun terakhir di antaranya karena tekanan kurs rupiah, defisit neraca perdagangan, suku bunga yang meningkat, krisis ekonomi global, FDI global yang menurun dan perang dagang AS-China. Menurut Rokhmatussa'dyah \& Suratman (2015) penanaman modal asing dipengaruhi oleh beberapa faktor antara lain stabilitas ekonomi dan stabilitas keuangan juga beberapa faktor lainnya.

Menurut Septifany et al. (2015) nilai tukar mata uang suatu negara mampu menjadi faktor yang mendorong masuknya investasi ke negara tujuan. Hal ini disebabkan karena kuatnya mata uang negara tempat investasi mampu membuat hasil investasi para investor asing mengalami kenaikan. Nilai tukar dapat menjadi penanda dari dari faktor yang mempengaruhi FDI.

Menurut Mayes et al. (2015) stabilnya nilai tukar suatu negara akan lebih memudahkan investor untuk menghitung dengan benar seberapa banyak biaya produksi yang akan dikeluarkan sewaktu kegiatan produksi berlangsung, serta harapan untuk mendapatkan kembali investasi yang telah dikeluarkan. Selain biaya produksi yang mudah untuk diperhitungkan, nilai tukar suatu negara juga memudahkan investor untuk menghitung return atau laba yang akan diperoleh. Ketidakstabilan nilai tukar suatu negara membuat para investor asing ragu untuk menanamkan modalnya di negara tersebut karena ketidakpastian biaya yang akan mereka keluarkan serta ketidakpastian keuntungan dan pengembalian modal yang akan dia dapatkan dari investasi tersebut. Risiko nilai tukar tidak hanya mempengaruhi keuntungan langsung, melainkan juga mempengaruhi aliran keuntungan dimasa depan. Hal tersebutlah yang dapat membuat para investor dari negara asing mempertimbangkan akan melakukan investasi dinegara tersebut atau tidak 
Putri, N.K., Komara, \& Setyowati, T. (2021). Pengaruh Nilai Tukar, Pertumbuhan Ekonomi, Inflasi, dan Suku Bunga ...

karena nilai tukar negara yang akan diinvestasikan terhadap negara asalnya akan berpengaruh terhadap keuntungan yang akan didapatkan. Hal ini sejalan dengan penelitian yang dilakukan oleh Sari \& Baskara, (2018) yang menunjukkan adanya hubungan positif dan signifikan antara nilai tukar dengan investasi asing langsung/ FDI di Indonesia. Hal ini juga sejalan dengan penelitian yang dilakukan oleh Abdul Hadi et al. (2018) hasil dari penelitian mereka menjelaskan bahwa nilai tukar memiliki hubungan yang signifikan terhadap FDI. Febriana \& Muqorobbin (2014) juga melakukan penelitian terhadap pengaruh nilai tukar rupiah dengan investasi asing langsung. Hasil penelitian tersebut menjelaskan dalam jangka pendek terdapat hubungan yang positif antara nilai tukar rupiah terhadap dollar AS dengan investasi asing langsung yang ada di Indonesia. Namun peneli-tian tersebut bertentangan dengan penelitian yang dilakukan oleh (Purba \& Hidayat (2015). Hasilnya menunjukkan bahwa tidak terdapat pengaruh signifikan antara nilai tukar dengan investasi langsung asing/FDI. Penelitian tersebut sejalan dengan penelitian Septifany, et al. (2015).

Menurut mereka, secara parsial nilai tukar rupiah memiliki hubungan yang negatif dan signifikan terhadap investasi asing langsung di Indonesia. Dari beberapa penelitian tersebut dapat disimpulkan bahwa nilai tukar merupakan salah satu faktor yang menjadi bahan pertimbangan oleh calon investor asing. Selain nilai tukar, stabilitas ekonomi juga dapat dilihat dari tingkat inflasi disuatu negara. Inflasi dapat diartikan sebagai peningkatan harga secara umum dan terus menerus dalam periode waktu tertentu.
Apabalia disuatu negara tingkat inflasinya tinggi hal tersebut menjelaskan bahwa ekonomi di negara tersebut tidak stabil yang dapat dikatakan bahwa pemerintah tersebut tidak dapat menyeimbangkan perekonomian. Hal tersebut sesuai dengan penelitian Septifany (2015). Penelitian ini mengatakan bahwa adanya hubungan negatif antara inflasi dengan investasi asing langsung. Penelitian tersebut sejalan dengan penelitian yang dilakukan oleh Kurniasari (2018). Penelitian ini mengatakan bahwa variabel inflasi berpengaruh negatif dan signifikan dalam jangka pendek dan jangka panjang. Penelitian ini juga sejalan dengan penelitian yang dilakukan oleh Mayes et al. (2015). Hasil penelitian tersebut mengatakan bahwa adanya hubungan negatif yang tidak signifikan antara inflasi dengan realisasi FDI di Indonesia antara tahun 1998-2013. Stabilitas keuangan dapat dilihat dari pertumbuhan ekonomi dan juga tingkat suku bunga suatu negara. Menurut Hasyim (2017) pertumbuhan ekonomi dapat diartikan sebagai peningkatan output barang dan jasa tertentu dalam periode waktu tertentu, atau dengan kata lain bahwa pertumbuhan ekonomi adalah proses naiknya kapasitas produksi suatu perekonomian yang direalisasi dalam bentuk kenaikan pendapatan nasional. Semakin baik perekonomian negara tersebut maka akan banyak pula investor yang ingin menanamkan modalnya di negara tersebut, karena tingkat kegagalan usahanya lebih rendah. Hal ini sejalan dengan penelitian yang dilakukan oleh Dewi \& Triaryati (2015). Berdasarkan hasil analisis ditemukan bahwa pertumbuhan ekonomi berpengaruh positif signifikan terhadap investasi asing langsung. Hal ini sejalan dengan penelitian 
yang dilakukan oleh Sari \& Baskara (2018). Hasil penelitian ini menunjukkan bahwa pertumbuhan ekonomi memiliki pengaruh yang positif dan tidak signifikan terhadap investasi asing langsung.

Suku bunga merupakan salah satu indikator dalam menentukan apakah seseorang akan melakukan investasi atau memilih untuk menabung. Apabila suku bunga rendah akan menyebabkan investasi akan bertambah, hal ini sesuai dengan penelitian Dewi \& Triaryati (2015) menurut mereka suku bunga memiliki hubungan negatif dan signifikan terhadap investasi.

Semakin tinggi tingkat suku bunga di suatu negara akan menyebabkan investor enggan untuk menanamkan modalnya. Hal ini sejalan dengan penelitian yang dilakukan oleh Sari \& Baskara (2018), penelitian tersebut mengatakan bahwa suku bunga memiliki hubungan yang negatif dan signifikan terhadap investasi asing langsung. Menurut Ernita dalam Sari \& Baskara (2018) investasi yang melemah terjadi akibat adanya peningkatan suku bunga dan sebaliknya. Namun hal tersebut bertentangan dengan penelitian yang dilakukan oleh Septifany (2015).

Hasil penelitian tersebut menjelaskan bahwa suku bunga berpengaruh positif secara signifikan terhadap investasi asing langsung. Hal ini sejalan dengan penelitian yang dilakukan oleh Astuty \& Siregar (2018). Menurut mereka tingkat suku bunga memiliki hubungan yang positif namun tidak signifikan terhadap investasi asing langsung di Indonesia.

\section{METODE PENELITIAN}

Menurut Sugiyono (2017) metode penelitian merupakan suatu cara ilmiah untuk mendapatkan sebuah data dengan kegunaan tertentu. Metode penelitian yang digunakan penulis pada penelitian ini adalah metode explanatory research dengan menggunakan pendekatan kuantitatif. Menurut Sugiarto (2017) penelitian eksplanatori merupakan penelitian yang memiliki tujuan untuk merumuskan sebuah hipotesis baru sehubungan dengan masalah yang diteliti. Metode $e x$ planatory research dengan pendekatan kuantitatif digunakan untuk mengetahui causal explanation dari variabel independen yaitu nilai tukar Rupiah, pertumbuhan ekonomi, tingkat inflasi, dan tingkat suku bunga terhadap variabel dependen yaitu investasi asing langsung. Dengan metode ini dapat dijelaskan pengaruh variabel bebas yaitu nilai tukar Rupiah, pertumbuhan ekonomi, tingkat inflasi, dan tingkat suku bunga terhadap variabel dependen yaitu investasi asing langsung.

Menurut Unaradjan (2019) "sampel adalah bagian dari populasi yang mempunyari ciri-ciri atau keadaan tertentu yang akan diteliti". Menurut Yusuf (2017) "sampel merupakan sebagian dari populasi yang terpilih dan mewakili populasi tersebut". Metode sampel yang digunakan dalam penelitian ini merupakan sampel jenuh. Sampel yang digunakan dalam penelitian ini antara lain, data Nilai Foreign Direct Invest-ment Net Inflow, Official Exchange Rate (per USD), Nilai Produk Domestik Bruto Indonesia (Gross Domestic Pruduct per Capita), Consumer Price Index dan Lending Interest Rate di Indonesia periode tahun 1986-2019. Data tahun 1998 (krisis ekonomi) tidak dimasukkan ke dalam sampel dikarenakan data pada tahun tersebut merupakan data outlier. 
Putri, N.K., Komara, \& Setyowati, T. (2021). Pengaruh Nilai Tukar, Pertumbuhan Ekonomi, Inflasi, dan Suku Bunga ...

Teknik pengolahan dan analisis data yang digunakan adalah analisis sta-tistik deskriptif, regresi linear berganda, uji asumsi klasik, analisis koefisien korelasi, dan uji hipotesis. Adapun model penelitian menggunakan persamaan regresi linier berganda.

$$
\mathrm{Y}=\mathrm{a}+\mathrm{b}_{1} \mathrm{X}_{1}+\mathrm{b}_{2} \mathrm{X}_{2}+\mathrm{b}_{3} \mathrm{X}_{3}+\mathrm{b}_{4} \mathrm{X}_{4}+\mathrm{e}
$$

\section{HASIL DAN PEMBAHASAN}

\section{Hasil Uji Analisis Statistik Deskriptif}

Tabel 1. Hasil Uji Analisis Statistik Deskriptif Descriptive Statistics

\begin{tabular}{cccccc}
\hline & $\mathrm{N}$ & Min & Max & Mean & Std. Deviation \\
\cline { 2 - 6 } & Statistic & Statistic & Statistic & Statistic & Statistic \\
\hline$(\mathrm{X} 1)$ & 33 & 1282.56 & 14236.94 & 7377.2547 & 4442.65734 \\
\hline$(\mathrm{X} 2)$ & 33 & 609035.39 & 58508674.98 & 17753861.1700 & 18727524.41000 \\
\hline$(\mathrm{X} 3)$ & 33 & 3.03 & 20.48 & 7.5340 & 3.50938 \\
\hline$(\mathrm{X} 4)$ & 33 & 10.37 & 27.66 & 16.9845 & 4.72922 \\
\hline $\begin{array}{c}\text { Valid N } \\
\text { (listwise) (Y) }\end{array}$ & 33 & -4550355286.00 & 25120732060.00 & 7448223852.0000 & 9061267182.00000 \\
\hline \multicolumn{7}{c}{} & & & & \\
\hline
\end{tabular}

Hasil penelitian (2020)

Berdasarkan hasil perhitungan dari analisis statistik deskriptif pada tabel di atas, diperoleh data mean, standar devaiasi, nilai maximum dan nilai minimum dari 33 sampel data yang digunakan. Variabel Investasi Asing. Langsung (Y) menunjukkan bahwa rata-rata (mean) sebesar Hasil Uji Asumi Klasik
7448223852.0000. Standar deviasi dari varibel investasi asing langsung di Indonesia sebesar 9061267182.00000. Nilai maximum variabel investasi asing langsung di Indonesia sebesar 25120732060.00 dan nilai minimum sebesar 4550355286.00 .

Tabel 2. Hasil Uji Kolmogrov-Smirnov

\begin{tabular}{|c|c|c|}
\hline \multicolumn{3}{|c|}{ One-Sample Kolmogorov-Smirnov Test } \\
\hline \multicolumn{3}{|r|}{ Unstandardized Residual } \\
\hline $\mathrm{N}$ & & 33 \\
\hline \multirow[t]{2}{*}{ Normal Parameters ${ }^{a, b}$} & Mean & -.0000061 \\
\hline & Std. Deviation & 3521125738.00000000 \\
\hline \multirow[t]{3}{*}{ Most Extreme Differences } & Absolute & .127 \\
\hline & Positive & .073 \\
\hline & Negative & -.127 \\
\hline \multicolumn{2}{|l|}{ Test Statistic } & .127 \\
\hline \multicolumn{2}{|c|}{ Asymp. Sig. (2-tailed) } & $.193^{\mathrm{c}}$ \\
\hline \multicolumn{3}{|c|}{ a. Test distribution is Normal. } \\
\hline \multicolumn{3}{|l|}{ b. Calculated from data. } \\
\hline \multicolumn{3}{|c|}{ c. Lilliefors Significance Correction. } \\
\hline asil penelitian (2020) & & \\
\hline
\end{tabular}

Pada penelitian ini nilai signifikansi sebesar $0.193<0,05$. Maka dapat diinterpretasikan bahwa residual dari model regresi terdistribusi secara normal. Berikut merupakan hasil dari metode uji probability plot. 


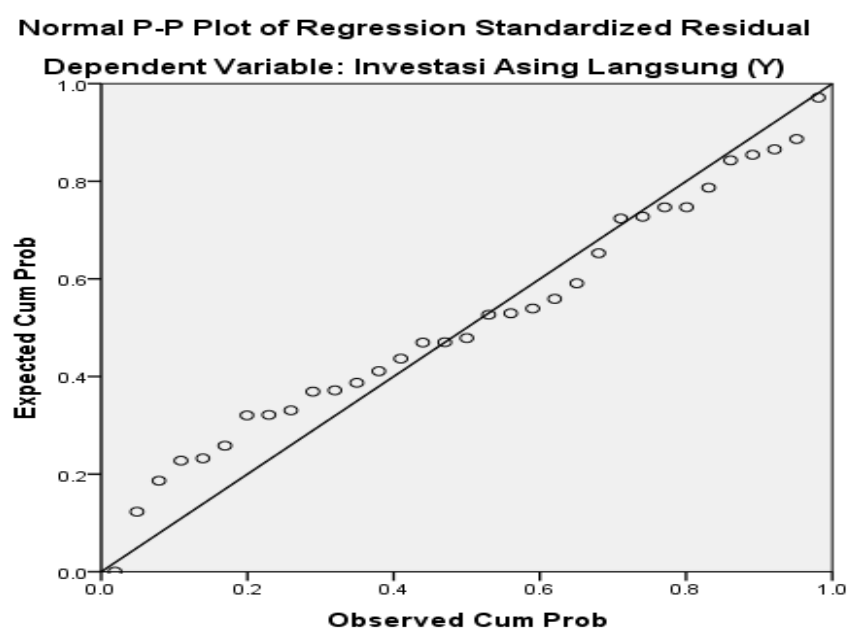

Gambar 2. Grafik Normal P- Plot

Berdasarkan gambar hasil grafik normal $P-P$ del regresi linear terdistribusi normal. KesimpulPlot diatas, dapat dilihat bahwa pola menunjukan an yang dapat diperoleh berdasarkan dua metode penempatan titik di sekitar garis diagonal berada uji asumsi klasik di atas adalah model regresi di sekitar garis diagonal dan mengikuti arah garis pada penelitian ini terdistribusi secara normal. diagonal sehingga dapat disimpulkan bahwa mo1) Uji Multikolinearitas

Tabel 3. Hasil Uji Multikolinearitas

\begin{tabular}{llll}
\hline \multicolumn{3}{c}{ Coefficients $^{\boldsymbol{a}}$} \\
\hline \multicolumn{1}{c}{ Model } & \multicolumn{2}{c}{ Collinearity Statistics } \\
\cline { 2 - 4 } & \multicolumn{2}{c}{ Tolerance } & VIF \\
\hline 1 & Constant) & .171 & 5.838 \\
\cline { 2 - 3 } & Nilai Tukar Rupiah (X1) & .167 & 6.003 \\
\cline { 2 - 3 } & Pertumbuhan Ekonomi (X2) & .457 & 2.187 \\
\cline { 2 - 3 } Tingkat Inflasi (X3) & .197 & 5.077 \\
\cline { 2 - 3 } Tingkat Suku Bunga (X4) & \\
\hline a. Dependent Variable: Investasi Asing Langsung (Y) \\
\hline \multicolumn{2}{l}{ Hasil penelitian (2020) }
\end{tabular}

Nilai Tolerance dari seluruh variabel inde- VIF di bawah 10.00. Dengan demikian dapat dipenden memiliki nilai yang lebih besar dari 0.10. simpulkan bahwa model regresi bebas dari multiSedangkan nilai Value Inflation Factor (VIF) selu- kolinearitas. ruh variabel bebas/independen memiliki nilai

Tabel 4. Hasil Uji Heteroskedastisitas

\begin{tabular}{|c|c|c|c|c|c|c|c|c|}
\hline \multicolumn{9}{|c|}{ Coefficients $^{a}$} \\
\hline & & \multirow{2}{*}{\multicolumn{2}{|c|}{$\begin{array}{c}\text { Unstandardized } \\
\text { Coefficients }\end{array}$}} & \multirow{3}{*}{$\begin{array}{c}\text { Standardize } \\
d \\
\text { Coefficients } \\
\end{array}$} & \multirow[b]{4}{*}{$\mathrm{T}$} & \multirow{2}{*}{\multicolumn{3}{|c|}{$\begin{array}{l}\text { Collinearity } \\
\text { Statistics }\end{array}$}} \\
\hline & & & & & & & & \\
\hline & & & & & & & Toleranc & \\
\hline & Model & $\mathrm{B}$ & Std. Error & Beta & & Sig. & $e$ & VIF \\
\hline \multirow[t]{4}{*}{1} & (Constant) & 3600187012 & 410538878 & & .877 & .388 & & \\
\hline & & .000 & 3.000 & & & & & \\
\hline & Nilai Tukar Rupiah (X1) & -301714.159 & 233605.808 & -.532 & -1.292 & .207 & .171 & 5.838 \\
\hline & Pertumbuhan Ekonomi & 101.050 & 56.198 & .751 & 1.798 & .083 & .167 & 6.003 \\
\hline
\end{tabular}

(X2) 
Putri, N.K., Komara, \& Setyowati, T. (2021). Pengaruh Nilai Tukar, Pertumbuhan Ekonomi, Inflasi, dan Suku Bunga ...

\begin{tabular}{|c|c|c|c|c|c|c|c|}
\hline \multicolumn{8}{|c|}{ Coefficients $^{a}$} \\
\hline \multirow[b]{2}{*}{ Model } & \multicolumn{2}{|c|}{$\begin{array}{c}\text { Unstandardized } \\
\text { Coefficients }\end{array}$} & \multirow{2}{*}{$\begin{array}{c}\begin{array}{c}\text { Standardize } \\
d \\
\text { Coefficients }\end{array} \\
\text { Beta }\end{array}$} & \multirow[b]{2}{*}{$\mathrm{T}$} & \multirow[b]{2}{*}{ Sig. } & \multicolumn{2}{|c|}{$\begin{array}{c}\text { Collinearity } \\
\text { Statistics }\end{array}$} \\
\hline & $\mathrm{B}$ & Std. Error & & & & $\begin{array}{c}\text { Toleranc } \\
e \\
\end{array}$ & VIF \\
\hline Tingkat Inflasi (X3) & $\begin{array}{r}59141309.7 \\
80 \\
\end{array}$ & $\begin{array}{r}181027994 . \\
100 \\
\end{array}$ & .082 & .327 & .746 & .457 & 2.187 \\
\hline $\begin{array}{l}\text { Tingkat Suku Bunga } \\
\text { (X4) }\end{array}$ & $\begin{array}{r}- \\
70255939.6 \\
00\end{array}$ & $\begin{array}{r}204651974 . \\
400\end{array}$ & -.132 & -.343 & .734 & .197 & 5.077 \\
\hline
\end{tabular}
Hasil penelitian (2020)

Pengujian heteroskedastisitas pada penelitian ini dengan uji Glejser, seluruh variabel bebas memiliki signifikansi lebih dari 0.05. Sehingga dapat disimpulkan bahwa model regresi pada penelitian ini tidak memiliki permasalahan heteroskedastisitas. Selain dengan Uji Glejser., untuk menguji terjadinya heteroskedastisitas dalam model regresi dapat dilakukan dengan melihat grafik scatterplot. Berikut merupakan grafik scatterplot.

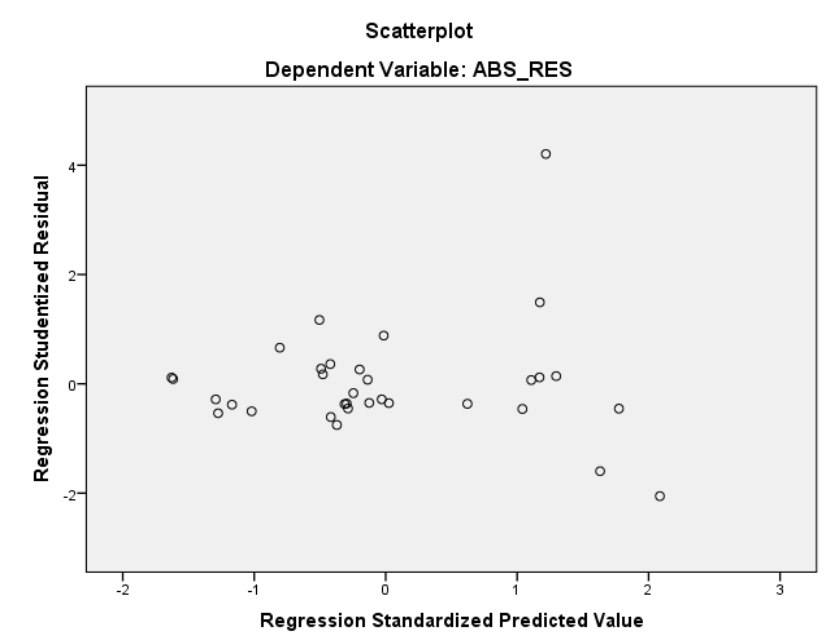

Gambar 3. Grafik Scatterplot

Berdasarkan gambar hasil grafik normal $P_{-} \quad$ berada di sekitar garis diagonal dan mengikuti P Plot di atas, dapat dilihat bahwa pola menun- arah garis diagonal sehingga dapat disimpulkan jukkan penempatan titik disekitar garis diagonal bahwa model regresi linear terdistribusi normal. 2) Uji Autokorelasi

Tabel 5. Hasil Uji Autokorelasi

\begin{tabular}{lc}
\hline \multicolumn{2}{c}{ Runs Test } \\
\hline \multicolumn{2}{c}{ Unstandardized Residual } \\
\hline Test Value ${ }^{\mathrm{a}}$ & -201690751.20000 \\
\hline Cases $<$ Test Value & 16 \\
\hline Cases $>=$ Test Value & 17 \\
\hline Total Cases & 33 \\
\hline Number of Runs & 14 \\
\hline $\mathrm{Z}$ & -1.057
\end{tabular}




\begin{tabular}{lc}
\hline \multicolumn{2}{c}{ Runs Test } \\
\hline \multicolumn{2}{c}{ Unstandardized Residual } \\
\hline Asymp. Sig. (2-tailed) \\
\hline a. Median \\
\hline Hasil penelitian (2020)
\end{tabular}

Penelitian ini menggunakan uji Run Test, dapat disimpulkan bahwa tidak terdapat autonilai dari Asympt Sig. (2-tailed) yaitu sebesar korelasi pada model regresi di dalam penelitian 0.291 yang berarti lebih besar dari 0.05. Sehingga ini.

\section{Analisis Regresi Linear Berganda}

Tabel 6. Hasil Analisis Regresi Linear Berganda

\begin{tabular}{|c|c|c|c|c|c|c|c|c|}
\hline \multicolumn{9}{|c|}{ Coefficients $^{\mathbf{a}}$} \\
\hline & \multirow[b]{2}{*}{ Model } & \multicolumn{2}{|c|}{ Unstandardized Coefficients } & \multirow{2}{*}{$\begin{array}{l}\text { Standardized } \\
\text { Coefficients } \\
\text { Beta }\end{array}$} & \multirow[b]{2}{*}{$\mathrm{T}$} & \multirow{2}{*}{$\begin{array}{l}\mathrm{Si} \\
\text { g. }\end{array}$} & \multicolumn{2}{|c|}{$\begin{array}{l}\text { Collinearity } \\
\text { Statistics }\end{array}$} \\
\hline & & B & Std. Error & & & & Tolerance & VIF \\
\hline \multirow[t]{10}{*}{1} & (Constant) & 20462103690. & 6359928471. & & 3.217 & .0 & & \\
\hline & & 000 & 000 & & & 03 & & \\
\hline & $\begin{array}{c}\text { Nilai Tukar Rupiah } \\
\text { (X1) }\end{array}$ & -1663931.630 & 361894.161 & -.816 & -4.598 & $\begin{array}{r}.0 \\
00\end{array}$ & .171 & 5.838 \\
\hline & Pertumbuhan & 608.666 & 87.061 & 1.258 & 6.991 & .0 & .167 & 6.003 \\
\hline & Ekonomi (X2) & & & & & 00 & & \\
\hline & Tingkat Inflasi (X3) & 738157071.60 & 280442402.6 & .286 & 2.632 & .0 & .457 & 2.187 \\
\hline & & 0 & 00 & & & 14 & & \\
\hline & Tingkat Suku Bunga & - & 317039868.1 & -.526 & -3.177 & .0 & .197 & 5.077 \\
\hline & $(\mathrm{X} 4)$ & 1007155477.0 & 00 & & & 04 & & \\
\hline & & 00 & & & & & & \\
\hline
\end{tabular}

Hasil penelitian (2020)

Berdasarkan hasil perhitungan dari analisa regresi linear berganda pada tabel diatas, maka dapat diperoleh persamaan regresi untuk mengetahui faktor-faktor dalam

$$
\begin{aligned}
& \mathrm{Y}=20462103690.000+(- \\
& \text { 1663931.630) } \mathrm{X}_{1}+608.666 \mathrm{X}_{2}+ \\
& 785634688.300 \mathrm{X}_{3}+(-1007155477.000) \mathrm{X}_{4}+
\end{aligned}
$$
memprediksi berikut:

\section{Hasil Uji Hipotesis}

\begin{tabular}{|c|c|c|c|c|c|c|}
\hline \multicolumn{7}{|c|}{ Coefficients $^{a}$} \\
\hline & & \multicolumn{2}{|c|}{ Unstandardized Coefficients } & \multirow{2}{*}{$\begin{array}{c}\begin{array}{c}\text { Standardized } \\
\text { Coefficients }\end{array} \\
\text { Beta } \\
\end{array}$} & \multirow[b]{2}{*}{$\mathrm{t}$} & \multirow[b]{2}{*}{ Sig. } \\
\hline & & B & Std. Error & & & \\
\hline \multirow[t]{6}{*}{1} & (Constant) & 20462103690.00 & 6359928471.0 & & 3.217 & .003 \\
\hline & & 0 & 00 & & & \\
\hline & $\begin{array}{c}\text { Nilai Tukar Rupiah } \\
\text { (X1) }\end{array}$ & -1663931.630 & 361894.161 & -.816 & -4.598 & .000 \\
\hline & $\begin{array}{l}\text { Pertumbuhan } \\
\text { Ekonomi (X2) }\end{array}$ & 608.666 & 87.061 & 1.258 & 6.991 & .000 \\
\hline & Tingkat Inflasi (X3) & 738157071.600 & $\begin{array}{r}280442402.60 \\
0\end{array}$ & .286 & 2.632 & .014 \\
\hline & Tingkat Suku Bunga & -1007155477.000 & 317039868.10 & -.526 & -3.177 & .004 \\
\hline
\end{tabular}

1) Uji T

Tabel 7. Hasil Uji T 
Putri, N.K., Komara, \& Setyowati, T. (2021). Pengaruh Nilai Tukar, Pertumbuhan Ekonomi, Inflasi, dan Suku Bunga ...

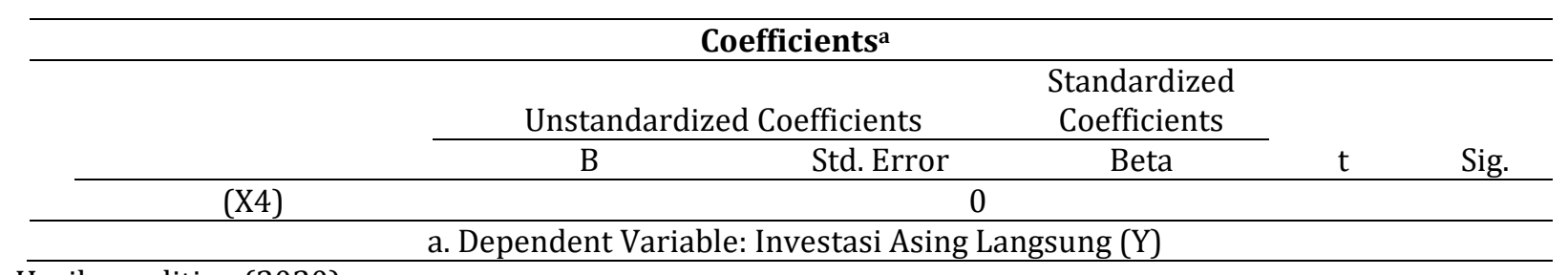

Hasil penelitian (2020)

Berikut merupakan penjelasan dari hasil uji parsial atau uji T di atas:

1. Pengaruh Nilai Tukar Rupiah (X1) terhadap Investasi Asing Langsung ( $\mathrm{Y}$ ) memiliki nilai $t_{\text {hitung }}=-4.598$ dan $t_{\text {tabel }}(0.025 ; 28)=2.048$. Hasil tersebut menjelaskan bahwa thitung ($4.598)<t_{\text {tabel }}(-2.048)$ dengan nilai signifikansi sebesar $0.000<0.05$. Maka dapat dikatakan bahwa Nilai Tukar Rupiah (X1) secara parsial berpengaruh negatif dan signifikan terhadap Investasi Asing Langsung (Y). Sehingga dapat disimpulkan bahwa $\mathrm{HO}_{1}$ ditolak yang berarti $\mathrm{H} 1_{1}$ diterima.

2. Pengaruh Pertumbuhan Ekonomi (X2) terhadap Investasi Asing Langsung $(\mathrm{Y})$ memiliki nilai $t_{\text {hitung }}=6.991$ dan $t_{\text {tabel }}(0.025 ; 28)=$ 2.048. Hasil tersebut menjelaskan bahwa $t_{\text {hitung }}$ $6.991>t_{\text {tabel }} 2.048$ dengan nilai signifikansi sebesar $0.000<0.05$. Maka dapat dikatakan bahwa Pertumbuhan Ekonomi (X2) secara parsial berpengaruh positif dan signifikan terhadap Investasi Asing Langsung (Y). Sehingga dapat disimpulkan bahwa $\mathrm{HO}_{2}$ ditolak yang berarti $\mathrm{H} 1_{2}$ diterima.
3. Pengaruh Tingkat Inflasi (X3) terhadap Investasi Asing Langsung $(\mathrm{Y})$ memiliki nilai $\mathrm{t}_{\text {hitung }}=$ 2.632 dan $t_{\text {tabel }}(0.025 ; 28)=2.048$. Hasil tersebut menjelaskan bahwa $t_{\text {hitung }} 2.632>t_{\text {tabel }}$ 2.048 dengan nilai signifikansi sebesar $0.014>$ 0.05. Maka dapat dikatakan bahwa Tingkat Inflasi (X3) secara parsial berpengaruh positif dan signifikan terhadap Investasi Asing Langsung (Y). Sehingga dapat disimpulkan bahwa $\mathrm{HO}_{3}$ ditolak yang berarti $\mathrm{H}_{3}$ diterima.

4. Pengaruh Tingkat Suku Bunga (X4) terhadap Investasi Asing Langsung (Y) memiliki nilai $t_{\text {hitung }}=-3.177$ dan $t_{\text {tabel }}(0.025 ; 28)=2.048$. Hasil tersebut menjelaskan bahwa thitung ($2.519)<t_{\text {tabel }}(-2.046)$ dengan nilai signifikansi sebesar $0.004<0.05$. Maka dapat dikatakan bahwa Tingkat Suku Bunga (X4) secara parsial berpengaruh negatif dan signifikan terhadap Investasi Asing Langsung (Y). Sehingga dapat disimpulkan bahwa $\mathrm{HO}_{4}$ ditolak yang berarti $\mathrm{H} 1{ }_{4}$ diterima.

5. Uji F

Tabel 8. Hasil Uji F

\begin{tabular}{|c|c|c|c|c|c|c|}
\hline \multicolumn{7}{|c|}{ ANOVAa $^{a}$} \\
\hline & Model & Sum of Squares & $\mathrm{Df}$ & Mean Square & $\mathrm{F}$ & Sig. \\
\hline \multirow[t]{5}{*}{1} & Regression & 22306635670000000000 & 4 & 55766589190000 & 39.357 & $.000^{\mathrm{b}}$ \\
\hline & & 00.000 & & 0000000.000 & & \\
\hline & Residual & 39674644690000000000 & 28 & 14169515960000 & & \\
\hline & & 0.000 & & 000000.000 & & \\
\hline & Total & $\begin{array}{r}26274100140000000000 \\
00.000\end{array}$ & 32 & & & \\
\hline
\end{tabular}


Putri, N.K., Komara, \& Setyowati, T. (2021). Pengaruh Nilai Tukar, Pertumbuhan Ekonomi, Inflasi, dan Suku Bunga ...

Berdasarkan hasil pengujian analisis koefisien determinasi (Adjusted $R^{2}$ ) diatas, dapat diketahui bahwa koefisien determinasi (Adjusted $R^{2}$ ) yang ditunjukan oleh nilai Adjusted $\mathrm{R}^{2}$ sebesar 0.827 atau $82.7 \%$. Hasil tersebut menjelaskan bahwa variabel-variabel independen dalam penelitian ini yaitu, Nilai Tukar Rupiah (X1), Pertumbuhan Ekonomi (X2), Tingkat Inflasi (X3) dan Tingkat Suku Bunga (X4) mempengaruhi variasi variabel dependen dalam penelitian ini yaitu Investasi Asing Langsung (Y) sebesar $82.7 \%$. Sedangkan $17.3 \%$ dipengaruhi oleh variabel lain yang tidak dimasukan kedalam model penelitian ini seperti pajak, regulasi pemerintah, utang luar negeri, ekspor dan impor, infrastruktur, dan sebagainya.

\section{SIMPULAN}

1. Berdasarkan hasil uji parsial (uji T) dapat disimpulkan bahwa :

1) Variabel Nilai Tukar Rupiah memiliki nilai $t_{\text {hitung }}(-4.598)<t_{\text {tabel }}(-2.048)$ dengan nilai signifikansi sebesar $0.000<0.05$. Maka dapat dikatakan bahwa Nilai Tukar Rupiah secara parsial berpengaruh negatif dan signifikan terhadap Investasi Asing Langsung. Penguatan mata uang rupiah membuat investor asing tertarik untuk menginvestasikan dananya di Indonesia, hal ini dikarenakan pengutan mata uang rupiah menunjukkan kondisi ekonomi negara dalam keadaan stabil sehingga resiko investasi lebih kecil menjadi signal positif bagi investor untuk melakukan investasi langsung di Indonesia.
2) Variabel Pertumbuhan Ekonomi memiliki nilai thitung $6.991>t_{\text {tabel }} 2.048$ dengan nilai signifikansi sebesar $0.000<0.05$. Maka dapat dikatakan bahwa Pertumbuhan Ekonomi secara parsial berpengaruh positif dan signifikan terhadap Investasi Asing Langsung. Pertumbuhan ekonomi yang tinggi yang akan meningkatkan ukuran pasar (Market Size). Dengan meningkatnya ukuran pasar (Market Size) berarti jumlah konsumen atau pembeli yang potensial meningkat. Pertumbuhan ekonomi yang tinggi juga meningkatkan pertumbuhan pasar. Pertumbuhan pasar yang tinggi berarti peluang bisnis yang ada di pasar juga semakin besar. Hal tersebut yang membuat investor asing tertarik untuk menanamkan dananya di negara yang pertumbuhan ekonominya baik.

3) Variabel Tingkat Inflasi terhadap Investasi Asing Langsung memiliki nilai thitung $2.632>t_{\text {tabel }} 2.048$ dengan nilai signifikansi sebesar $0.014<0.05$. Maka dapat dikatakan bahwa Tingkat Inflasi secara parsial berpengaruh positif dan signifikan terhadap Investasi Asing Langsung. Saat inflasi meningkat menandakan bahwa negara tersebut sedang mengalami kenaikan konsumsi. Kenaikan konsumsi menandakan permintaan barang dan jasa di negara tersebut juga meningkat, hal ini akan menyebabkan cepatnya perputaran barang atau jasa di suatu negara yang diikuti dengan kenaikan produksi. Hal tersebut yang menyebabkan keuntungan bagi para 
investor meningkat. Sehingga investor tertarik untuk berinvestasi di negara tersebut.

4) Variabel Tingkat Suku Bunga terhadap Investasi Asing Langsung memiliki thitung ($3.177)<t_{\text {tabel }}(-2.048)$ dengan nilai signifikansi sebesar $0.004<0.05$. Maka dapat dikatakan bahwa Tingkat Suku Bunga secara parsial berpengaruh negatif dan signifikan terhadap Investasi Asing Langsung. Apabila tingkat suku bunga pinjaman (Lending Interest Rate) terlalu tinggi akan mengakibatkan biaya modal yang tinggi juga (High Cost) yang membuat aliran Foreign Direct Investment sulit masuk ke suatu negara.

2. Berdasarkan hasil uji simultan (Uji F) diperoleh nilai $F_{\text {hitung }}(39.357)>F_{\text {tabel }}(2.714)$ dengan nilai signifikansi $0.000<0.05$. Berdasarkan hasil tersebut dapat dikatakan bahwa variabel Nilai Tukar Rupiah, Pertumbuhan Ekonomi, Tingkat Inflasi dan Tingkat Suku Bunga berpengaruh secara bersama-bersama atau simultan dan signifikan terhadap Investasi Asing Langsung.

3. Berdasarkan hasil pengujian analisis koefisien determinasi (Adjusted $R^{2}$ ) di atas, dapat diketahui bahwa koefisien determinasi (Adjusted $R^{2}$ ) yang ditunjukan oleh nilai Adjusted $\mathrm{R}^{2}$ sebesar 0.827 atau $82.7 \%$. Hasil tersebut menjelaskan bahwa variabel-variabel independen dalam penelitian ini yaitu, Nilai Tukar Rupiah, Pertumbuhan Ekonomi, Inflasi dan Suku Bunga mempengaruhi variasi variabel dependen dalam penelitian ini yaitu Investasi Asing Langsung sebesar 82.7\%. Sedangkan 17.3\% dipengaruhi oleh variabel lain yang tidak dimasukkan ke dalam model penelitian ini.

\section{DAFTAR PUSTAKA}

Ahmad, Ferhan Kareem, et.all. (2017). Foreign Direct Investment, Aggregate Demand Conditions and Exchange Rate Nexus: A Panel Data Analysis of BRICS Economies. "Research in International Business and Finance".

Albassam. (2014). Foreign Direct Investments, Economic Growth, and Employment: A Global Perspective. "The Journal of Social, Political, and Economic Studies", Vol 39.

Ali, Mukhtiar dan Imran Riaz Malik. (2017). Impact of Foreign Direct Investment On Economic Growth of Pakistan. "Iqra University Islamabad".

Ambarini, Lestari. 2015. Ekonomi Moneter. Bogor: In Media.

Apostolov, Mico. (2017). FDI Uppers and Downers: A Macedonian Case Study. "New Global Stud", Vol 11, No. (1)

Astuti, Fuji dan Ina Namora Putri Siregar. (2018). Analisis Produk Domestik Bruto, Infrastruktur, Nilai Tukar dan Tingkat Suku Bunga Terhadap Investasi Asing Langsung di Indonesia. "Jurnal Konsep Bisnis dan Manajemen", Vol 5, No.1.

Aziz, Omar G. dan Anil V. Mishra. (2015). Determinants of FDI inflows to Arab economies. "The Journal of International Trade \& Economic Development".

Bank Indonesia Website. (Online), (https://www.bi.go.id, akses 11 April 2019).

Bank Dunia Website. (Online), (https://www.worldbank.org, akses 14 Mei 2019).

Danilevičienè, Irena dan Vilma Lukšytè. (2017). Tiesioginių Užsienio Investiciju İtakos Šalies Ekonomikos Konkurencingumui Vertinimas. "Verslas XXI Amžiuje Business In XXI Century”. Vol. 9, No. (2).

Darsono dan R. Eki Rahman. 2018. Pasar Valuta Asing Teori dan Praktik. Depok: PT. Raja Grafindo Persada.

Dewi, Putu Kartika dan Nyoman Triaryati. (2015). Pengaruh Pertumbuhan Ekonomi, Suku Bunga dan Pajak Terhadap Investasi Asing Langsung. "E-Jurnal Manajemen Unud", Vol. 4, No. 4.

Dewi, Tania Melinda dan Hendry Cahyono. (2016). Pengaruh Pertumbuhan Ekonomi, Bi Rate, dan Inflasi Terhadap Investasi Asing Langsung Di Indonesia. "Jurnal Pendidikan Ekonomi (JUPE)", Volume 4 No. 3 edisi Yudisium.

Fachrulloh, Nizar Eko dan Mukhammad Kholid Mawardi. (2018). Analisis Determinan Foreign Direct Investment di Negara Emerging Market Asia Periode 2011-2015. "Jurnal Administrasi Bisnis $(J A B) "$,Vol. 57 No. 2.

Febriana, Asri dan Masyhudi Muqorobbin. (2014). Investasi Asing Langsung Di Indonesia Dan Faktor Faktor Yang Mempengaruhinya. "Jurnal Ekonomi dan Studi Pembangunan", Volume 15, Nomor 2. 
Halim, Muh Abdul. 2018. Teori Ekonomi Makro. Jakarta: Mitra Wacana Media.

Hasyim, Ali Ibrahim. 2017. Ekonomi Makro. Depok: Kencana.

Hidayat, Naufan Faris, Mochammad Al Musadieq dan Ari Darmawan, Pengaruh Foreign Direct Investment, Nilai Tukar Dan Pertumbuhan Ekonomi Terhadap Ekspor (Studi Pada Nilai Ekspor Non Migas Indonesia Periode Tahun 2005-2015). "Jurnal Administrasi Bisnis (JAB)”, Vol. 43 No.1, halaman 173.

Igamo, Alghifari Mahdi. (2015). Pengaruh Resiko Ekonomi Terhadap Penanaman Modal Asing di Negara Asean (Studi Kasus Perbandingan Antara Negara Indonesia, Malaysia, Singapura, Thailand, Filippina, Brunei Dan Myanmar). "Jurnal Ekonomi Pembangunan", Volume 32, No.2, 77.

Jufrida, Firdaus, dkk. (2016). Analisis Pengaruh Investasi Asing Langsung (FDI) dan Investasi Dalam Negeri Terhadap Pertumbuhan Ekonomi Indonesia. "Jurnal Perspektif Ekonomi Darussalam", Volume 2 Nomor 1.

Kurniasari, Indah. (2018). Analisis Pengaruh Suku Bunga, Inflasi, dan Nilai Tukar Terhadap Investasi Asing di Jawa Tengah Tahun 1990-2016. "Universitas muhammadiyah Surakarta".

Kurniawan, Rachmat. (2017). Pengaruh Foreign Direct Investment Terhadap Perekonomian Masyarakat Dumai Pasca Berlakunya Masyarkat Ekonomi Asean. "JOM FISIP", Vol. 4 No. 2.

Kweon, Arthur J, et.al. 2010. Manajemen Keuangan ,terjemahan Marcus Prihminto Widodo. Jakarta : PT Indeks.

Lubis, Rizky P, dkk. (2015). Faktor Faktor yang Mempengaruhi Investasi Asing Langsung pada Sektor Perkebunan di Indonesia. "Jurnal Bisnis \& Manajemen", Vol. XVI, No. 2.

Mangkuatmojo, Soegiyarto. 2015. Statistik Deskriptif. Jakarta: Rineka Cipta.

McCloud, Nadine dan Michael S. Delgado. (2018). Domestic Interest Rate and Foreign Direct Investment under Institutional Uncertainty.

Mishkin, Frederic S. 2017. Ekonomi Uang, Perbankan, dan Pasar Keuangan. Terjemahan oleh Barlev Nicodemus Hutagalung. Jakarta: Salemba Empat.

Niu, Mingyu. (2018). An Empirical study of the impact of the change in Real Effective Exchange Rate on China's inflow of Foreign Direct Investment. "All Graduate Plan B and other Reports", 1323.

Oktaviana, Cicy. (2016). Dampak Investasi Asing Langsung (FDI) Terhadap Pertumbuhan Ekonomi Indonesia 1980-2014. "Islamic University of Indonesian Economic Faculty".

Purba, Putri Sri Kasinta, Suhadak, Raden Rustam Hidayat. Pengaruh Impor Dan Nilai Tukar Terhadap Investasi Langsung Asing Di Indonesia (Studi Pada Bank Indonesia Periode Kuartal I 2006 - Kuartal Iv 2013). "Jurnal Administrasi Bisnis (JAB)”, Vol. 28 No. 1.
Putri, Novi Hasana dan Sudarsana Arka. (2017). Analisis Pengaruh PDB dan Kurs Dollar Amerika Terhadap Neraca Perdagangan Melalui Foreign Direct Investment Di Indonesia Tahun 1996-2015. "E-Jurnal EP Unud", Vol. 6, No. [9].

Purwanto, Erwan Agus dan Dyah Ratih Sulistyastuti. 2017. Metode Penelitian Kuantitatif Untuk Administrasi Publik Dan Masalah-Masalah Sosial. Yogyakarta: Penerbit Gava Media.

Razak, Abdul Hadi Abdul, et all (2018). Analyzing Sectorial Level Determinants of Inward Foreign Direct Investment (FDI) In ASEAN. "Polish Journal of Management Studies" Vol 17 No.2.

Rokhmatussa'dyah, Ana dan Suratman. 2015. Hukum Investasi \& Pasar Modal. Jakarta: Sinar Grafika.

Salvatore, Dominick. 2014. Ekonomi Internasional, terjemahan Romi Bhakti Hartanto dan Yanuar Heru Prakoso . Jakarta: Salemba Empat.

Samora, Remon. (Online). (https://nasional.sindonews.com/read/1354446/1 8/investasi-langsung-asing-meredup-adaap1542152014, akses 11 April 2019).

Sari, Gusti Agung Ayu Ratih Meita dan I Gde Kajeng Baskara. (2018). Pengaruh Pertumbuhan Ekonomi, Suku Bunga, dan Nilai Tukar Terhadap Investasi Asing Langsung di Indonesia. "E-Jurnal Manajemen Unud", Vol. 7, No.7.

Sarkodie, Samuel Asumadu dan Vladimir Strezov. (2018). Effect of foreign direct investments, economic development and energy consumption on greenhouse gas emissions in developing countries. "Department of Environmental Sciences".

Sayari, Karima. (2019). Institutional Efficiency and Attraction of Foreign Direct Investment to Developing countries. "International Journal of Economics and Finance", Vol. 11, No. 7.

Septifany, Amida Tri, dkk. (2015). Analisis Pengaruh Inflasi, Tingkat Suku Bunga, Nilai Tukar Rupiah Dan Cadangan Devisa Terhadap Penanaman Modal Asing di Indonesia (Studi Pada Bank Indonesia Periode Tahun 2006-2014). "Jurnal Administrasi Bisnis (JAB)", Vol. 25, 3.

Shopia, Aya dan Sri Sulasmiyati. (2018). Pengaruh Foreign Direct Investment, Ekspor, dan Utang Luar Negeri Terhadap Pertumbuhan Ekonomi Asean (Studi Pada Produk Domestik Bruto Indonesia, Malaysia, dan Thailand Periode Tahun 2007 2016). "Jurnal Administrasi Bisnis (JAB)". Vol. 61 No. 3.

Sjaroni, Bachrudin. 2016. Pengantar Ilmu Ekonomi Makro. Yogyakarta: Deepublish.

Sugiarto. 2017. Metodologi Penelitian Bisnis. Yogyakarta: Andi.

Sukirno, Sadano. 2016. Makroekonomi Teori Pengantar. Jakarta: PT. Rajagrafindo Persada

Tambunan, Rexsy S . (2015). Pengaruh Kurs, Inflasi, Libor dan PDB Terhadap Foreign Direct Invesment (FDI) di Indonesia. "JOM FEKON",Vol. 2 No.1.

Unaradjan, D. D. (2019). Metode Penelitian Kuantitatif. 
Unika Atma Jaya.

Yazdi, Soheila Khoshnevis, et.all. (2015). The relationship between tourism, foreign direct investment and economic growth: evidence from
Iran. "Routledge. New York University".

Yusuf, A. M. (2017). Metode Penelitian Kuantitatif, Kualitatif \& Penelitian Gabungan. Kencana. 